\title{
Diversification of Host Plants as a Strategy in the Control of Plant Diseases
}

\section{Henrique Maia Valério1 1 , Carlos Roberto Casela²}

\author{
${ }^{1}$ Laboratório de Ecologia de Microrganismos e Microbiologia Ambiental, Centro de Ciências Biológicas e da Saúde, \\ UNIMONTES, CEP 39401-089, Montes Claros, MG, Brazil (126) \\ ${ }^{2}$ Embrapa Milho e Sorgo, Caixa Postal 151, CEP 35701-970, Sete Lagoas, MG, Brazil
}

\begin{abstract}
With the purpose of to avoid or to reduce some of those inherent problems to the agricultural systems based on monoculture, it should be introduced and handled the diversity in the best possible way. In a high level, the monoculture of species is difficult of being modified, at least in short space of time. At the level of the varieties of plants, the diversification is relatively easy of being handled, mainly in the mixture form of cultivars, varieties or hybrid (simple, double or triples) in the farmings. These mixtures can be produced in commercial scale, with excellent results in relation to most of the experimental scales, or for small producers at a low cost, seeking a good level of control of diseases and stability in the productivity. The composition of the mixtures can be modified transiently to delay or to reduce the selection of new races capable to overcome the resistances of more than one of the components of a mixture. The main disadvantage is that the quality of the mixtures cannot be acceptable for the final consumer of the product of these diversified farmings. However, mixtures of varieties, hybrid or of lineages, can significantly improve the control of some of the most common diseases disseminated by the air and for the water. For this reason, cultural practices more diversified are, consequently, recommended to complement the resistance of the hosts, in matter, in the Sorghum bicolor-Colletotrichum sublineolum pathosystem and to reduce the selection pressure in fields.
\end{abstract}

\section{INTRODUCTION}

Only in the last a hundred years, that the farming in monoculture turned predominant in the agriculture industrialized in the field. The reasons were the simplicity in the planting, mechanization of harvesting and other operations, in such a way to provide the uniformity of the quality of the products of these farmings. However, the monoculture produced severe disadvantages, such as the largest vulnerability of the plants to the diseases, curses and injurious plants, besides the productive instability, that needed, for instance, of the use of pesticides, fertilizers and chemical fungicides in wide climbs. To avoid or to reduce some of the problems of the monoculture it would be necessary to introduce and to handle the diversity in a better way. In a high level, the monoculture of species is difficult of being modified, at least in a short space of time (WOLFE, 1997). AT level of the varieties, the diversification is easy of being handled, in the form of mechanical mixture of varieties directly in the planted areas. Therefore, mixtures can be produced commercially or for small farmers at a low cost, seeking to reach a good control of diseases and stability of the productivity.
WOLFE (1985) it has been defining the mixtures of you cultivate how being "mixtures of plants that vary for many characters, including resistance to the diseases, very away they have enough similarity for they be cultivated jointly". The mixtures do not cause drastic changes to the agricultural systems, they usually increase the stability of the farming's in relation to the productivity losses in monoculture and, in some cases, and they can reduce the need of application of pesticides (chemical insecticides) and fungicides. Plants used in mixtures should possess good agronomic characteristics (architecture of the plant) and they should be similar phenotypically for important characters, including maturity of grains, height, quality and types of grains.

The main mechanism for which the mixtures operate in a system is the decrease of the tax of progress of the diseases, for eliminating a reasonable number of spores in each cycle of multiplication of the pathogens and, in matter, for Colletotrichum sublineolum, a polycyclic pathogen. Of this it sorts things out, the spores are eliminated of the epidemic process by the deposition in resistant plants (alodeposition) and reduced, concomitantly auto

This article is published under the terms of the Creative Commons Attribution License 4.0

Author(s) retain the copyright of this article. Publication rights with Alkhaer Publications.

Published at: http://www.ijsciences.com/pub/issue/2017-08/

DOI: 10.18483/ijSci.1377; Online ISSN: 2305-3925; Print ISSN: 2410-4477 
infection, in already woven committed of susceptible plants, as well as for dilution because of the largest distances among more susceptible plants to the pathogen (LANNOU, 2001). Besides, another effect would serialize the fact that the expansion of the epidemic could be reduced for the induction of resistance answer in susceptible plants for races avirulents to the host plant. Therefore, the most apparent results are the suppression of the level of progress of the disease for the performance of epidemic and physiologic mechanisms, in the population of host plants, such as effect of inocula dilution, effect barrier and resistance induction.

One of the situations in that the mixtures can be of economical interest is for the protection of genotypes susceptible hosts with superior agronomic characters. In cases of that type, the job of you cultivates susceptible in combination with a plant lower agronocamically, mainly as for the low productivity, but genetically resistant to the diseases, it could be an efficient solution and of low cost (GARRET \& MUNDT, 1999). The genetic diversity of the population of cultivated plants offers a great potential for the genetic control of some pathogenic agents. Such a measured one can be gotten in cultivation areas, through the sowing of crops (lineages, hybrid or commercial varieties) with different resistance levels to the diseases, or specifically to a certain disease, in different areas, sowing multilines (isogenic lines in the field). In another way, as in the mixtures with sorghum lineages (GUIMARÃES et al., 1998; VALÉRIO et al., 2004), they can be combined two, three or more plants, each one with different genes for resistance, or also with plants that have several genes inside for resistance of its own genetic outline. Several evidences of efficient control of diseases exist, inside of the field, through the use of intra-specific diversity in such patossystems as the sorghum (C. sublineolum), wheat (Puccinia striiformes), oats (Puccinia coronata) and barley (Erysiphe graminis) (WOLFE, 1985; MUNDT, 2002, MUNDT, 2002a, VALERIO et al., 2004). Seemingly, the substitution of the susceptible plants in a pure cultivation for resistant plants would reduce the amount of available susceptible tissues for expansion of an epidemic. Besides, the movement of the inoculums from a susceptible plant for another would have as obstacle or barrier as the presence of resistant plants in the mixture.

Regarding the mixtures of cultivars, another basic subject is been the increase of the individual genetic diversity among cultivated plants is compatible or not with the production and with the commercialisation of this production system. Mixture of genotypes and varieties or even among species, in the consortium form, they are common in the traditional agriculture. Current evidences also suggest that the mixtures can and they should be used in the modern commercial agriculture (MUNDT et al., 1999; BOWDEN et al., 2001). There are some disadvantages regarding the use of mixtures and that should be outstanding. The necessary time used for the mixture of seeds and the specialized equipments for these tasks are not still available for most of the small farmers. The manual preparation of the mixtures of seeds to be planted in larger areas can consume plenty of time. The possible incompatibility of components of the mixture can be a potential problem. This problem restricts the choice of components that can be used in the mixtures, being observed similar agronomic characters such preferentially as height and maturation of the grains (BOWDEN et al. 2001). This care was also observed, regarding choice of the different sorghum lineages (Sorghum sublineolum) adopted in the work developed by VALÉRIO et al. (2004), as base for the use of restoring lineages $(\mathrm{R})$ and male-sterile lineages (B) in the elaboration of the mixtures. Another possible potential agronomic disadvantage of the mixtures would be the loss of the opportunity of adjusting handling practices adapted specifically each one of the components of the mixture, mainly due to the differences in plants density, fertilization, planting time, etc. Experiences accomplished in Germany, Poland, Austria and USA, regarding the use of the mixtures in farmings of great commercial scale of barley, oats and wheat demonstrated that the appropriate quality of malt could be maintained in face of the wide job of cultivar mixtures and. So, of this it sorts things out, being made possible fully for its commercialisation, since, several companies acquire products of different varieties for, later, during the improvement of the same ones, to mix them in order to homogenize the final product (WOLFE, 2000).

\section{MIXTURES IN AGRO ECOSYSTEMS}

Recently the phytopatologists have been detaching the reasons for which some epidemics of diseases in plants are more frequent in areas cultivated than in ecosystems formed by natural vegetation. This observation has been taking the conclusion that the epidemics are, in great measure, the result of the human interference in the swinging (balance) of the nature (THRESH, 1981). The conditions that allow to a certain pathogen to reach epidemic levels are particularly favoured for the extension of cultivations genetically homogeneous, common tendency in many systems of modern cultivations (ZADOKS \& SCHEIN, 1979, SWANSTON et al., 2005, SWANSTON et al., 2006). Therefore, cultivation areas surrounded by great focuses, healthy particularly vulnerable and, through the occupation of remote areas for great farmings, the invasion for pathogens is facilitated by the presence of great areas of susceptible hosts. 
Some conditions, in agreement with BERGER (1977), they are necessary for the development, in great scale, of a quite noxious illness and among them, they can be outstanding the following ones:

- Expansion of the farmings;

- Aggregation of areas of cultivations;

- Accumulation of the plants cultivated potentially hosts;

- Decrease of the diversity of species, of varieties, as well as of the host populations;

- Increase of the cut patterns, rotation and/or extensive monoculture;

- Use of fertilizers, irrigation and other modifications of cultivation of farmings.

A direct relationship exists between the intensity of cultivation and the risk of an epidemic. The intensive and semi-intensive systems of cereals in Asia, Argentina or oriental Europe have smaller risks of epidemics than the intensive systems of the European Union, United States and in the areas of tropical climates of Brazil (ALTIERI, 1999). This way, the purpose of measures of control of diseases would be to prevent that damages provoked by the same ones, do not cross a certain level where the usefulness and the requested incomes are reduced significantly. In a general way, they can be applied three epidemic strategies to reduce to the minimum the losses provoked by the diseases:

- To eliminate or to reduce the initial inocula or even delaying its emergence in the beginning of the planting period;

- To decrease or to lower the tax of development of the diseases (r) during the period of growth of the farming;

- To reduce the time of exhibition of a culture to the pathogens, using varieties of short duration or fertilization and irrigation practices that avoid that the growth of a culture is slow.

The most general strategies than they can be used to reduce the incidence of a disease understand: to avoid, to exclude or to eradicate when possible, the main pathogenic agents, to protect the host plants, to develop resistance in the varieties and cultivated hybrid and to do a previous treatment of the plants already infected (ZADOKS \& SCHEIN, 1979).

Some methods of biological and cultural control that are used until or during the period of sowing of the plants they are essential to reduce to the minimum an illness. The controls routine applied with the sowing include: rotation of cultures, heating of the soil by exhibition in the sun or it burns her, temporary flood, tilled and correction of the soil with very organic matter. The tilled of the soil is capable to destroy the residues of other farmings and to accelerate the decomposition and the colonization of beneficial microorganisms (COOK, 1982).
The eradication of wild alternative hosts, just as Sudan grass, neighbours to the sorghum farmings and susceptible to the same diseases, it can be an useful method, as well as in the case of the Puccinia graminis and Cranartium ribicola, whose control requests the retreat of the alternative hosts Berberis vulgaris and Ribes spp., respectively. The more common methods for diseases control during the sowing make use of varieties, resistant lineages, when available, and seeds of materials (plants) free from pathogenic agents, through previous treatment with fungicides or active compositions with antifungal activity (antocianines, in some varieties of Sorghum bicolor) (MUNK, 1983).

The genetic resistance is an important mechanism that contributes with the suppression of the diseases of plants and many works have been accomplished with regard to the description of this resistance type (VANDERPLANCK, 1982; MCDONALD \& LINDE, 2002). The resistance of the host plant can be divided in two types: vertical and horizontal. The vertical resistance is effective against some races (genotypes) of pathogenic species to the plants and ineffective against other. VANDERPLANK (1982) it emphasizes that the vertical resistance, usually, provides high resistance levels or immunity and, usually, it is of monogenic inheritance. He has been giving himself a lot of emphasis to the use of the vertical resistance for the control of the diseases, due to the fact of being it simple inheritance, of easy identification and for providing high resistance levels. For some diseases, without a doubt, the widespread use of vertical resistance can select virulent genotypes of the pathogens population quickly and to produce an ineffective genetic resistance (BROWNING \& FREY, 1969).

On the other hand, great attention has been rendering to other resistance type, supposedly different, that it has been denominated in several ways: general resistance, field resistance or simply horizontal. She is considered as a no specific resistance to any race and that, usually, it is incomplete, that is, does not suppress the reproduction of the pathogens entirely and, usually, it is inherited quantitatively. VANDERPLANK (1982) it considered that the horizontal resistance is more stable than the vertical; without doubts this stability has been attributing to the specificity lack regarding the races and not to a great possible amount of genes that control the horizontal resistance, if compared to the vertical.

Among other methods used in the handling and control of diseases, they deserve some prominence that can be more appropriate in agreement with the characteristics of the pathogens to be controlled. For instance, in England the potatoes cultivated in 
seasoned areas are attacked rarely by Phytophtora infestans, once the same ones are picked before the period of maximum reproduction of the pathogen. The variations in the spacing of the rows of the plants and the depth of the sowing are other methods that can contribute to the cultivation to avoid the direct contact with the inocula of the pathogen (PALTI, 1981). Many cultivation systems can affect the diseases. If similar cultures don't share of the same pathogenic agent and they are not planted in succession, there is a good probability so that any inocula maintained in the soil has lost the viability due to the absence of its host or that even it has been eliminated by antagonism with other microorganisms of the soil.

Many of these cultivation methods as rotation of cultures, elimination of alternative hosts, deep sow of the cultural remains of another farming, collation of cultures not correlated, use of barrier cultivations can be incorporate to alternative systems of agricultural production and, without doubts, its adoption will depend, largely, of an amount of environmental, biological, economical and humans factors (ALTIERI, 1999). Clearly, it is known that the cultivation systems owe if it adapts very well with the interactions crop/agent, pathogen/environment adapts of each cultivated area. Besides, the demands should be considered for an economical control, safe and fast of a certain disease.

It was just in the last a hundred years that the use of the monoculture became predominant, more vehemently during the Green Revolution, powders II world war, returned, mainly, for the commercial agriculture in the fields and in farmings of great scale. The reasons for the adoption of the monoculture are explained by the simplicity in the planting, automated in its largest part, crop and operations of improvement of the products that allowed the uniformity of the quality of the same ones, facilitating its commercialisation. However, the monoculture in great scale produced drastic modifications, that in its immense majority, they came disadvantageous for the such agro ecosystems as larger vulnerability to the diseases, proliferation of curses and weeds (injurious plants, that work a lot of times as alternative hosts), productive instability (biomass/ha), which disputed, for instance, use in wide scale of pesticides (insecticides), herbicides, chemical fertilization and growth factors (NEWTON et al., 2002).

In opposition the all those problems, the improvers of plants are trying to obtain resistance to the diseases and the most severe curses through genetic improvement of plants. However, the success is relative, tends in its view small durability, mainly because of the scale in monoculture, as well as of the scarce use of handling techniques, that no the chemist, as in the pulverizations, for the resistant varieties soon after its liberation for the agricultural production (WOLFE, 1997). The limited handling means the use of resistant varieties individually in great scale that, usually, it takes to the selection of new races of the pathogens, especially for the high variability already described for several pathogens, especially $C$. sublineolum, capable to overcome the resistance of those host plants.

Of the several monoculture levels, they are worth to be outstanding the following ones, of the etiological agents of the diseases point of view, according to GACEK (1997):

- Monoculture of species: the wheat production, corn or sorghum, as only species in great areas, in its great part at the present time, in system of direct planting, or in consecutive rotations among varieties of the same species;

- Monoculture of varieties: through just of the job of species, only varieties are sometimes used continually in great areas, propitiating a maximum opportunity for the pathogens selection and insectcurse that are well adapted for if they multiply in a variety in matter;

- Resistance monoculture: even different varieties they can be used simultaneously, but with the same resistance genes and, in that way, if they present identical for a certain pathogen, favouring its proliferation.

With the purpose of to avoid or to reduce some of those inherent problems to the agricultural systems based on monoculture, it should be introduced and handled the diversity in the best possible way. In a high level, the monoculture of species is difficult of being modified, at least in short space of time. At the level of the varieties of plants, the diversification is relatively easy of being handled, mainly in the mixture form of cultivars, varieties or hybrid (simple, double or triples) in the farmings (FINCKH et al., 2000). These mixtures can be produced in commercial scale, with excellent results in relation to most of the experimental scales, or for small producers at a low cost, seeking a good level of control of diseases and stability in the productivity. The composition of the mixtures can be modified transiently to delay or to reduce the selection of new races capable to overcome the resistances of more than one of the components of a mixture. The main disadvantage is that the quality of the mixtures cannot be acceptable for the final consumer of the product of these diversified farmings. However, mixtures of varieties, hybrid or of lineages, can significantly improve the control of some of the most common diseases disseminated by the air and for the water such an as, rusts, mildew, septoriosis, anthracnose, helmintosporiosis, rincosporidiosis, etc. 
Therefore, the fact that in extensive farmings the use of fungicides becomes impracticable economically and the previous treatment doesn't guarantee future immunity on the emergency of the young plants (MUNCK, 1997).

The use of mixture of genotypes as strategy of control of diseases is relatively old, having registration of experiments in the United States of America (USA), dating from 1889 (WARBURTON, 1915, mentioned by MARTINELLI, 1993). This strategy has been used in the last years in traditional systems of agriculture in several countries, as in the Soviet former-union (Russia, mainly), where it was sowing, with success, the winter wheat "Bezostaja 1" for the control of diseases. This strategy is also used commercially in barley, in Germany and Canada (WOLFE, 1985) and rice, in Japan, seeking the control of the rice blast fungus, provoked by the etiological agent Magnaporthe grisea (KOIZUMI \& KATO, 1987).

The resistance of the hosts has been the most economical form to handle foliar diseases of the sorghum, including anthracnose (C. sublineolum) and helmintosporiosis (Exserohilum turcicum). However, the improvement programs are looking for cultivars resistant to multiple pathogens, what demands time and, in most of the cases, the resistance sources are effective against just some or few pathogenic species. Characteristic symptoms are easily identifiable and the resistance sources have been located mainly in ICRISAT (1983) (International Crops Research Institute goes the Semi-Arid Tropics, Hyderabad, India). However, now the use thoroughly distributed of the resistant cultivars around of the world it is limited because these materials sometimes possess undesirable characteristics in the taste, colour, and quality of the grains as for the processing and, mainly, low incomes in the field. Associated to these factors, the same can be seem when cultivars with the sought characteristics are obtained in the improvement programs, there is always the potential for the emergency of new pathogens races that can overcome the resistance of the hosts (WOLFE, 2000).

The broken resistance for pathogens that present high variability levels as $C$. sublineolum and E. turcicum is especially common. In this way, the use of alternative strategies for the handling of diseases just as the use of the mixtures of cultivars, seeking the simultaneous control of two or more epidemics beyond just as the anthracnose and the helmintosporiosis. For this reason, cultural practices more diversified are, consequently, recommended to complement the resistance of the hosts, in matter, in the Sorghum bicolor-Colletotrichum sublineolum pathosystem and to reduce the selection pressure (ODVODY \& HEPPERLY, 1992; DUNCAN \&
MILLIANO, 1995; NGUGI, 1998, CASELA et al., 2000, NGUGI et al., 2001, NGUGI et al., 2002).

The vertical resistance, although highly efficient in the control of diseases, is of little durability, becoming ineffective after the appearance of a new race of the pathogen that can dominate her. Due to the lowers durability of the vertical resistance (qualitative resistance) in cultivations genetically uniforms, the use of more effective strategies has been seeking for the control of epidemics (BROWNING \& FREY, 1969; BROWNING \& FREY, 1981; MUNDT, 2002, MUNDT et al., 2002). The application of the horizontal resistance (quantitative resistance) it is one of the most suitable options in the improvement of plants seeking to obtain more durable resistance to the diseases. The form as this resistance type acts on a pathogens population seems not to be based on the recognition receiver-elicitor typical of the vertical resistance for a certain pathogen race and, consequently, it would act more evenly against several races. One of the problems in the application of the quantitative resistance presents in mixtures or even in multilines, it can be the erosion, similar to the break of a specific gene of resistance. The erosion phenomenon is more difficult of being observed or detected, once populations of corresponding pathogens can use a pathogenicity distribution that can vary considerably of year for year, as a result of a strong interaction among the environment and the pathogen that it can select quantitative characters, in the plants and in the pathogens (MUNDT, 2002).

MCDONALD et al. (1988) studied the effectiveness of a mixture of barley genotypes in the control of four races of Rhynchosporium secallis, through the lines progenitors' use and derived lines of 45 generations of crossings at random. The authors observed that $17 \%$ of all tested mixtures presented smaller severity of diseases than foreseen with base in the severity of their components individually. In the mixtures obtained starting from lineages in that there was a co-evolution or host-pathogen interaction, smaller severity of disease was observed, when compared with mixtures of components chosen at random.

WOLFE \& BARRET (1980) tested more than 150 mixtures for 11 years, as for the control of diseases and production. More than $80 \%$ of the studied mixtures had medium productions $8 \%$ above the medium production of their components, individually, besides efficient control of diseases. The remaining of the mixtures, very away they did not propitiate effective control of diseases, they presented medium production $2 \%$ above their individual components. 
MUNDT \& LEONARD (1986), they studied the effect of the genotypic unit area of the host (basic space area for an unit of the host) about the effectiveness of the mixture of genotypes for the control of epidemics of rust of the bean plant (Uromyces appendiculatus) and rust common of the corn (Puccinia sorghi) for three years. Mixtures of resistant and susceptible plants were used, with four different genotypic unit areas, gotten through the alternation of spatial arrangement of the susceptible host genotype inside of stands. In the mixtures with corn genotypes, the authors observed reductions from 25 to $50 \%$ in the severity of disease in the susceptible host in comparison with susceptible pure lines, they found similar result for mixtures of bean genotypes.

The effectiveness of the mixture of genotypes is reduced with the increase of the area of the genotypic unit area, in conditions in that the initial inoculum is distributed uniform or randomly in the culture (MUNDT \& LEONARD, 1985). In spite of the quantitative relationship between efficiency of the mixture and the genotypic unit area, the mixtures of genotypes promote significant control of the disease, protecting the plants against pathogens with high variability and delaying the development of epidemics (LEONARD, 1969; MARSHAL et al., 1986; BROWNING, 1988).

The multilines exercise its effect through the reduction of the amount of initial inoculums (X0) and of the infection tax (r) (BROWNING \& FREY, 1969). The components of the mixtures, with genes of vertical resistance reduce the proportion of the population of the pathogen capable to begin the epidemic. Besides, the presence of resistant plants in the mixture reduces the chance of a viable spore to reach a susceptible plant, reducing the tax of spread of the pathogen (WOLFE, 1985).

Identified three mechanisms contribute to the reduction of the spread of the pathogen in the mixture:

1 - Planting density: in the mixture, the distance among susceptible individuals to the same pathogen is increased, contributing to reduction of the spread of the pathogen and, consequently, of the epidemic (WOLFE, 1985; RAM et al., 1989);

2 - Effect barrier: the resistant plants occupy space among the susceptible plants. In general, resistant plants with wide leaves and thick stems can increase the value of this mechanism (WOLFE, 1985; RAM et al., 1989);

3 - Resistance induction: the infection for spores of an avirulent pathotype induces a response in the plant, restricting the infection for virulent pathotypes [CHIN \& WOLFE, 1984; CHIN \& WOLFE, 1984 (the); WOLFE, 1985; RAM et al., 1989].
In agreement with MICHEL et al. (1997), the simultaneous action of the mechanisms of the decrease and proportionate barrier for the mixture of genotypes of oats can promote a negative effect on the rust of the leaf (Puccinia coronata f. sp. Avenae), resulting in linear decreasing relationship of the disease intensity, in function of the density of the susceptible plants. In that work there was not difference among the averages of the incomes of grains or of the values of the weight of the hectolitre obtained by the genotypes in pure cultivation. Probably, the most important mechanism of action of mixtures of genotypes is in the decrease of the space density of susceptible plants, in other words, of the genotypic unit area (WOLFE, 1985).

The use of mixtures than isogenic lines and multilines is preferred because their components are different in many characteristics, mainly in relation to the resistance to several diseases and it can protect the culture against other stress sources (BROWNING \& FREY, 1969). Other attraction to the use of the mixtures of genotypes is in the fact that the control of diseases is reached with very smaller cost for the producer (SIFUENTES \& BARRERA, 1989), besides having the advantage of obtaining stable productions, when compared with uniform farmings (WOLFE, 1985).

\section{MODELS OF EVALUATION OF THE PROGRESS OF THE DISEASES IN FARMINGS} Epidemiologists of diseases of plants come along several decades, being interested in the evaluation of the temporary increase or on the progress of diseases in plants, through a model that is used as reference: the curves of progress of diseases. The simple descriptive models of growth diseases have been serving, sometimes, to characterize the global pattern of the evolution of diseases in function of the time (PENNYPACKER et al., 1980; BERGER 1981; LUKE \& BERGER 1982; THAL et al., 1984; SUBBA RAO et al., 1990) or in time and space (BERGER \& LUKE 1979; JEGER 1983; HEADRICK \& PATAKY 1988; DAMICONE et al., 1990). LEONARD \& MUNDT (1984) told that the tax of progress of diseases modifies in the components with quantitative resistance, just as in the mixtures of lineages, but probably, just during the exponential phase of growth of an epidemic.

In at least two areas, those that register losses in farmings (FERRANDINO \& ELMER, 1992) or field evaluation for partial or quantitative resistance, the use of the obtained data starting from the disease progress curves were improved later through the calculation of the area under disease progress curve (AUDPC). This measured it has been used systematically to check the variations that, undoubtedly, they are seen in the curves of progress 
of diseases, as well as to integrate all of the aspects of disease in relation to the development of the host. The applicability of these calculations frequently is related to the field evaluation for high resistance levels. A representative group of publications regarding the use of evaluation of quantitative resistance (horizontal) using AUDPC is accomplished with fungi causes of foliate diseases in annual cultures (JEGER \& VILJANENROLLINSON, 2001), such as the sorghum, where there are many cycles of multiplication of the pathogens (policyclic epidemics), along the growth station. Usually, these evaluations and sampling methods collect of six or more collections of data during the transport of the experiments and they are quite informative as for the behaviour and evolution of the diseases, especially for epidemics as the anthracnose (CASELA et al., 2001).

The use of the calculation of the area under disease progress curve (AUDPC) as a quantitative measure of resistance to diseases, mainly in cultivars of corn, it requests the repetitive access to the pathogenic process, very away, for the typical sigmoid curves of progress of diseases this repetition procedure is unnecessary. JEGER \& VILJANEN-ROLLINSON (2001) were used AUDPC, through a derived mathematical procedure of this method, to estimate two different points from data. A field selection with 10 cultivars with and without the yr18 gene, that checks stripe rust resistance were inoculated with two pathotypes of Puccinia striiformis and they accessed the percentage of the leaf area infected during seven to eight weeks, during the period of growth station. Through the AUDPC calculations directly of the leaves data, estimated for the equations of volume areas calculation, the values were correlated against the AUDPC estimated values, being obtained an excellent correspondence. Therefore, an estimate of obtained AUDPC of three points of data, supplies an equivalent amount, so much of the point of view of information, as for the procedures based on repetition of evaluation of diseases.

Several authors developed mathematical models that intend to describe the response in the populations of the pathogens with the use of mixtures. All these models include the concept of stabilize selection, proposed by VAN DER PLANCK (1963), and based on the hypothesis that unnecessary genes for virulence would reduce the "fitness" of the pathogens, in the case of infection of a susceptible host. These models describe competition events between pathotypes or simple races, that have great specificity in a host genotype, but they are unable to develop in other. The complex races are capable to develop in several genotypes hosts; so far away they have a competitive disadvantage, that it would be proportional to the number of virulence genes that they would carry (BARRET, 1980; OSTERGAARD, 1983)

However, several other studies did not get to establish a direct correlation between fitness of the pathogens and the number of virulence genes presented against a certain group of genotypes hosts, among these the works with hidden Puccinia f. sp. tritici (KOLMER, 1995) or using Erysiphe graminis f. sp. tritici (BRONSON \& ELLINGBOE, 1986). Other studies involving one of the rusts of oats, Puccinia graminis f. sp. avenae, characterized pathotypes that carried unnecessary genes for virulence, distributed in wide climbs and for long periods in Canada.

Beside those whole considerations, mainly the cost of genes for virulence, other effects, probably of selective nature, they influence the evolution of the populations of the pathogens in the mixtures of host plants and they can reduce the tax with that the complex pathotypes grow. DILEONE \& MUNDT (1994) suggested that in the systems of mixtures of wheat genotypes against rust for Puccinia striiformis, the frequency of complex pathotypes also depends on the genetic background of the pathogens, as well as of the interactions among the races of the same ones, just as induced resistance, as well as of the composition of the mixture. Another selective effect, in addition, is attributed at the cost of the virulence to influence competition among simple and complex races in the mixtures of hosts; it would be the existence of differential selection of the isolates for the host genotypes (LANNOU \& MUNDT, 1997, CASELA et al., 2001). In the mixtures of hosts, simple races always reproduce in the same genotypes, what could result in the selection of more aggressive isolates and, as a consequence, in a simple increase of the fitness of a certain pathotype or more complex race.

\section{IMPLICATIONS AND CONSEQUENCES OF THE USE OF MIXTURES}

In mixtures of cultivars with different resistance genes, the pathogens are usually restricted to the susceptible hosts and the loss of spores on the resistant plants results in considerable reductions in the severity of the disease. Tends in view the easiness with that the pathogens quickly can develop new virulence or new combinations of virulences, it has been suggested that the use in wide climbs of mixtures of cultivars can select complex pathotypes (races) that would be capable growing largely, if not in all the components of a certain mixture (LANNOU, 2001). Otherwise, some studies come to lift certain restrictions to the use of this strategy, with base, mainly, in the reduction in the long period of the efficiency of the mixtures in to control and to provide a larger complexity in the populations of the 
pathogens. In terms of virulence combinations, several experimental studies have been aiming at the difficulty of doing generalizations, with base in conclusions that, in its majority, are contradictory (MUNDT, 2002).

LEONARD (1969) suggests that the use of the mixtures composed by hosts with different genetic "backgrounds" could increase the fitness for simple pathotypes through better selection of individuals adapted to the same hosts. On the other hand, the complex pathotypes would not own, in theory, to become better adapted to any one of the components of a certain mixture. However, CHIN \& WOLFE (1984) demonstrated that the way for which the data of expressed frequency of a certain genotype could influence interpretations of the evolutionary attributes significantly in the mixtures. These authors observed that the great relative frequency of complex races of Blumeria graminis on cultivars mixtures of barley was related as being highly effective in the reduction of the absolute frequency of simple races. After several years of extensive commercial use of barley mixtures in Eastern Germany, an increase in the relative frequency, but no absolute, $B$. graminis races combining more commonly virulence to two of the three resistance genes used in those mixtures.

In a relative recent study of field (VILLAREAL \& LANNOU, 2000), it was demonstrated in wheat mildew (Triticum aestivum) that the average of the effectiveness sporulation of complex isolates increased when the pathogen population was obtained of hosts cultivated in pure stands. However, no observed alteration in relation to the mixtures, where the averages of the frequencies of more complex genotypes stayed unaffected. This effect result of the selection for the increase of the effectiveness of the spores of simple races in the pure stands, independent of the virulence genes that are present in the population of the pathogens. The selection for genotypes of more aggressive pathogens, caused by the genetic "background" of the host can be probably widespread for many other species. Differential interactions among isolates and cultivars can be measured through the virulence genes and have been demonstrated for several fungal pathogens such as Puccinia spp (TODOROVA \& KURJIN, 1991), P. graminis (LOEGERING, 1951) and other rusts, as well as for Phytophthora infestans (JOHNSON \& TAYLOR, 1976) and C. sublineolum (NGUGI et al., 2001).

The pathogen evolution can be handled in some way since that a single mixture is not cultivated exclusively in a certain space of time and space (WOLFE \& BARRETT, 1980). For instance, new genotypes can be added to the mixtures of cultivars when agronomically superior plants will be liberated, in a rotation process of cultivars introduced in a mixture. It is also common that it naturally the spatial diversity of the mixtures occurs as well as many different host combinations or new bring better performances in the diseases control, and in the productivity in different areas from a certain area, considering the soil particularities, climate and handling practices of the diseases.

One of the subjects that turn more difficult the interpretations of the mixtures effects on the pathogen populations is given number of resistance genes is been, vertical or quantitative it will be more durable if used in a mixture when compared to the same numbers of genes employed sequencely in monoculture or even combined in a single host plant. No surprisingly, VALÉRIO et al. (2004) told that the total diversity values showed for all mixtures among different sorghum lineages, with different anthracnose resistance levels, did not supported pathogen populations phenotypically more diverse than that observed in their respective pure stands. Therefore, with rare exceptions (BROWNING \& FREY, 1981; MULLER et al., 1996), the diversity degree maintained in a mixture seems to be positively related to the degree of control of disease supplied by a certain mixture (DILEONE \& MUNDT, 1994). In a wider aspect, is that mixtures would select for the complex races frequency increase, that is, those with corresponding virulences to the more than a resistance gene in a mixture. In spite of the results of several experiments already accomplished have evidenced exactly that, in what it concerns to the frequencies of more complex races in the mixtures in relation to the predominance of simple races in pure portions (MUNDT, 2002). Such subject is extremely difficult of being tested requesting great areas or long intervals of time more appropriately to define them experimentally.

In an equal manner, in experiments of small scale, the relative frequency of complex genotypes of Blumeria graminis was larger in mixtures of barley cultivars than in their controls in pure stands (CHIN \& WOLFE, 1984a). HUANG et al. (1994) observed that selection for complexity was less intense in mixtures in lines (multilines) than in random mixtures, exactly as in the mixture experiments with sorghum lineages (VALÉRIO et al., 2004). In experiments of wide climbs space, these same fungi increased in complexity in areas in Germany, where mixtures of barley are cultivated in an area around the 360.000ha. In agreement with DILEONE \& MUNDT (1994), it is more difficult to determine the selective influence of the mixtures for clonal pathogens because virulence genes are not randomly associated with other genes that can influence the fitness of the pathogens. Along several experimental researches being used artificial inoculation of Puccinia 
graminis, KOLMER (1995), it tried to dissociate virulence of the genetic "background" of the pathogen. He observed strong selection for genotypes in the pathogen with virulence corresponding to three of the five present resistance genes in the barley multilines, although genotypes with five virulences have emerge in small frequency, like was observed for some pathotypes with virulence to all of the sorghum lineages tested in the random mixtures experiments (VALÉRIO et al., 2004). As well as in the sorghum mixtures, the same virulences were selected in the susceptible lineages and, of this it sorts things out, the selection pattern can be due more to the effects associated to the fitness of each complex race with specific combinations of virulence, than any selective effect attributed to an experimental model of multilines (KOLMER, 1995), as opposed to random mixtures. However, MUNDT (2002) tells that should have larger precaution in doing generalizations regarding the effects of the mixtures in the evolution of clonal pathogens.

Most of the models incorporated a point of view assuming that the fitness costs associated with virulence (in most of the cases, avirulence loss) they would serialize the main mechanism that would act against the selection to increase the virulence complexity in the pathogen. The advantage of a complex race in being capable to attack several host plants in a certain mixture probably bases on the hypothesis of acting contrarily for the reduction of the fitness associated to the loss of avirulence genes corresponding to the main genes of resistance. Usually the models suggest that it will always be difficult to prevent the eventual domain of complex races in a pathogen population, in such a way that, like observed with the sorghum mixtures in Brazil (VALÉRIO et al., 2004), the reduction of the aggressiveness of the isolated of $C$. sublineolum was combined with significant statistically levels of anthracnose control. Therefore, according to MUNDT (2002), there is unquestionable selection acting in the direction of the relative increase in the frequency of complex races in a mixture of plants.

PARLEVLIET (1981) told, through a complete revision on the concepts of virulence cost, there not to be virulence association with fitness of the pathogens as a general phenomenon. Recent molecular analyses indicated that some avirulence genes can contribute with the fitness of pleiotropic form and that the inactivation of such avirulence genes can favour the reduction of the fitness of the pathogens. Of this it sorts things out, selection for virulence in mixtures is much more complex than the relationship among static cost for fitness to the detriment of the unnecessary virulence. This occurs in such a way that the selection for modification on the pathogens fitness acts in a slower way than the selection in favour or against virulence genes (WOLFE \& BARRETT, 1980, WOLFE et al., 1981).

The relative data to the effects of the mixtures about the evolution of the populations of $C$. sublineolum evaluated in the experiments with sorghum in Brazil have several implications (VALÉRIO et al., 2004). Among the ones which the most important and maybe the most relevant was the capacity to control or to reduce the severity of the anthracnose of the sorghum on them susceptible cultivars in quite significant levels. The theories and the models are extremely useful in the evaluation of development of the epidemics of diseases of plants and in the evolution of the pathogens in the mixtures, especially when combined with the results of empirical studies. However, to evaluate the events related with the dynamics more precisely inside of a certain system, full of interferences and variables not controlled such as: biotic stresses, abiotical and climatic alterations during the period of the research can limit a more complete understanding of the effects of the mixtures in the development of the diseases and they are, therefore, subjects to the mistakes of the field studies (MUNDT, 2002; VALÉRIO et al., 2004, VALÉRIO et al., 2005).

Multilines, mixtures and other methods of genetic diversification should be considered as important tools for the handling of diseases, however they should take into account the particularities, the context and the needs for local agriculture through direct contact with the largest interested parties, the farmers. Not always the mixtures are the most appropriate strategies for the control certain disease, especially because the results of a farming genetically diversified are, in last analysis, the nonstandardization of the derived products of that determined mixture, and could create problems in the occasion of the commercialisation and or industrialization. However, several studies proved the effectiveness in the improvement of the income as well as in the stability of plants of high productivity when cultivated in mixtures with cultivars of low productivity, but with high resistance (ZHU et al., 2000)

Finally, given the need of a more maintainable agriculture, that it spares the solid and onerous use of the environmental and economical point of view, of chemical fungicides for the control of diseases, urgent consider some alternative approaches. Based on natural ecosystems and best balanced, the mixtures can play an important part next years, so much in the family agriculture, as in the handling areas and control of diseases of plants cultivated in wide production scale. 


\section{References}

1. ALTIERI, M. A. Agroecologia. 1999. Bases científicas para una agricultura sustentable. Nordan Comunidad, Uruguai.

2. BARRET, J. A. 1980. Pathogen evolution in multilines and variety mixtures. Z. Pflanzenschutz 87: 383-396.

3. BERGER, R. D. 1977. Application of epidemiological principles to achieve plant disease control. Annual Review of Phytopathology 15: 165183.

4. BERGER, R. D. 1981. Comparison of the Gompertz and logistic equations to describe plant disease progress. Phytopathology 71: 716-719

5. BERGER, R. D., \& LUKE, H. H. 1979. Spatial and temporal spread of oat crown rust. Phytopathology 69:1199-1201

6. BOWDEN, R., J. SHOYER, K. ROOZEBOOM, M. CLAASEN, P. EVANS, B. GORDON, B. HEER, K. JANSSEN, J. LONG, J. MARTIN, A. SCHLEGEL, R. SEARS, AND M. WITT. 2001. Performance of wheat variety blends in Kansas. Kansas State University Agric. Extension Bull. 128

7. BRONSON, C. R., \& ELlingBOE, A. H. 1986. The influence of four unnecessary genes for virulence on the fitness of Erysiphe graminis f. sp. tritici. Phytopathology 76: 154-158.

8. BROWNING, J. A. Current thinking in the use of diversity to buffer small grains against highly epidemic and variable foliar pathogens: problems and futures prospects. In: BREEDING STRATEGIES FOR RESISTANCE TO THE RUST OF WHEAT. CIMMYT, Mexico, D. F., 1988. P. 76090 .

9. BROWNING, J. A.; FREY, K. J. 1969. Multiline cultivars as a means of disease control. Annual Review Phytopathology 7: $355-382$

10. BROWNING, J. A.; FREY, K. J. 1981. The multiline concept in theory and practice (APUD ref. JENKYN \& PLUMB, 1981).

11. CASElA, C. R., SANTOS, F. G., FERREIRA, A. S. 2000. Associação de patogenicidade e diversidade fenotípica de Colletotrichum sublineolum, agente causal da antracnose em sorgo. Fitopatologia Brasileira 25: 517-521.

12. CASELA, C. R., FERREIRA, A. S. \& SANTOS, F. G. 2001. Differences in competitive ability among races of Colletotrichum sublineolum in mixtures. Fitopatologia Brasileira 26: $217-219$.

13. CHIN, K. M., WOLFE, M. S. 1984 (a). Selection on Erysiphe graminis in pure and mixed stands of barley. Plant Pathology 33: 535-546.

14. COOK, R. J. 1982. Use of pathogen suppressive soils for disease control. In: Suppressive Soils and Plant Disease. R. W. Schneider, ed. Minnesota: Am. Phytopath. Press. 1986. Interrelationships of plant health and the sustainability of agriculture. Am. J. Alter. Agri. 1: 19- 24.

15. DAMICONE, J. P., SNOW, J. P., BERGGREN, G. T. 1990. Spatial and temporal spread of soybean stem canker from an inoculum point source. Phytopathology 80:571-578

16. DILEONE, J. A.; \& MUNDT, C. C. 1994. Effect of wheat cultivar mixtures on populations of Puccinia striiformis races. Plant Pathology 43: 917-930.

17. DUNCAN, R. R., and DE MILLIANO, W. A. J. 1995. Plat disease control. Pages 35-74 in: Diseases Analysis Through Genetics and Biotechnology: Interdisciplinary Bridges to Improve Sorghum and Millet Crops. J. F. Leslie and R. A. Frederiksen, eds. Iowa State University Press, Ames.

18. FERRANDINO, F. J., ELMER, W. H. 1992. Reduction in tomato yield due to Septoria leaf spot. Plant Dis 76: 208211.

19. FINCKH, M. R.; GACEK, E. S.; GOYEAU, H.; LANNOU C.; MUNDT, C. C.; MERZ, U. 2000. Cereal variety and species mixtures in practice. Agronomie 20: 813-837.

20. GACEK, E. 1997. Summarized variety mixture information given to polish farmers. In: Variety mixtures in theory and practice, Wolfe, M. S., ed. European Union Variety and Species Mixtures working group of COST Action 817
21. GARRETT, K. A.; \& MUNDT, C. C. 1999. Epidemiology in mixed host populations. Phytopathology 89: 984-990.

22. GUIMARÃES, F. B., CASELA, C. R., SANTOS, F. G 1998. Controle da antracnose do sorgo através da utilização de misturas de cultivares. Summa Phytopathologica

23. HEADRICK, J. M., PATAKY, J. K. 1988. Spatial and temporal development of common rust in susceptible and partially resistant sweet corn hybrids. Phytopathology 78: 227-233.

24. HUANG, R.; KRANZ, J.; WELZ, H. G. 1994. Selection of pathotypes of Erysiphe graminis f. sp. Hordei in pure and mixed stands of spring barley. Plant Pathology 43: 458-470.

25. ICRISAT, 1983. Annual Report 1982. ICRISAT, Patancheru, A. P. 502 324, Índia.

26. JEGER, M. J. 1983. Analysing epidemics in time and space. Plant Pathol 32: 5-11.

27. JEGER, M. J.; VILJANEN-ROLLINSON, S. L. H. 2001 The use of the area under the disease-progress curve (AUDPC) to assess quantitative disease resistance in crop cultivars. Theorethical and Applied Genetics 102: 32-40

28. JOHNSON, R., \& TAYLOR, A. 1976. Spore yield of pathogens in investigations of the race-specificity of host resistance. Annu. Rev. Phytopathol 14: 97-119.

29. KOIZUMI, S.; KATO, H. 1987. Effect of mixed plantings of suscetible and resistant rice cultivars on leaf blast development. Annual Phytopathology Society Japan 53: 2838.

30. KOLMER, J. A. 1995. Selection in a heterogeneous population of Puccinia recondita $\mathrm{f}$. sp. tritici. Phytopathology 83: 909-914

31. LANNOU, C. 2001. Intrapathotype diversity for aggressiveness and pathogen evolution in cultivar mixtures. Phytopathology 91: 500-510.

32. LANNOU, C., MUNDT, C. C. 1997. Evolution of a pathogen population in host mixtures: Rate of emergence of complex races. Theor. Appl. Genet. 94: 991-999.

33. LEONARD, K. J. Genetic equilibria in host-pathogen systems. 1969 Phytopathology 59: 1858-1863.

34. LEONARD, K. J., MUNDT, C. C. 1984. Methods for estimating epidemiological effects of quantitative resistance to plant diseases. Theorethical Applied Genetics 67: 219-230.

35. LOEGERING, W. Q. 1951. Survival of races of wheat stem rust in mixtures. Phytopathology 41: 56-65.

36. LUKE, H. H., BERGER, R. D. 1982. Slow rusting in oats compared with the logistic and Gompertz models. Phytopathology 72:400-402.

37. MARSHALL, D. R.; BURDON, J. J.; MULLER, W. J. 1986. Multiline varieties and disease control. Effects of selection at different stages of the pathogen life cycle on the evolution of virulence. Theor. Applied Genetics 71: 801-809.

38. MARTINELLI, J. A. 1993. Uso de misturas varietais para o controle de doenças de plantas. Revisão Anual de Patologia de Plantas 1: 121-142.

39. McDONALD, B. A.; ALLARD, R. W.; WEBSTER, R. K. 1988. Responses of two-, three, and four-component barley mixtures to a variable pathogen population. Crop Science 28 : 447-452.

40. McDONALD, B. A., \& LINDE, C. 2002. Pathogen Population Genetics, Evolutionary Potential, and Durable Resistance. Annu. Ver. Phytopathol 40: 349-379.

41. MICHEL, C. A., MARTINELLI, U. A.; FREDERIZZI, L. C. 1997. Progresso da ferrugem da folha em misturas de genótipos de aveia. I. Efeitos de densidade e de barreira. Fitopatologia Brasileira 22: 479-482.

42. MULLER, K.; McDERMOTT, J. M.; WOLFE, M. S LIMPERT, E. 1996. Analysis of diversity in populations of plant pathogens: the barley powdery mildew pathogen across Europe. European Journal of Plant Pathology 102: 385-395.

43. MUNCK, L. 1997. Variety mixtures: 19 years of experience in Denmark. In: Variety Mixtures in theory and practice, Wolfe, M. S., ed. European Union Variety and Species Mixtures working group of COST Action 817. 
44. MUNDT, C. C. 2002. Performance of wheat cultivars and cultivars mixtures in the presence of Cephalosporium stripe. Crop Protection 21(2): 93-99.

45. MUNDT, C. C. 2002 (a). Use of multiline cultivars and cultivar mixtures for disease management. Annual Review of Phytopathology 40: 381-410.

46. MUNDT, C. C., \& LEONARD, K. J. 1986. Effect of host genotype unit area on development of focal epidemics of bean rust and common maize rust in mixture of resistant and susceptible plants. Phytopathology 76: 895-900.

47. MUNDT, C. C.; COWGER, C.; GARRETT, K. A. 2002. Relevance of integrated management to resistance durability. Euphytica (In press).

48. MUNDT, C. C.; COWGER, C.; HOFFER, M. E. 1999, Disease management using variety mixtures. In Septoria and Stagonospora Diseases of Cereals: A Compilation of Global Research, ed. M. Van Ginkel, A McNab, J Krupinsky, p: 111-116, Mexico, DF: CIMMYT.

49. MUNDT, C. C.; LEONARD, K. J. 1985. Effect of host genotype unit area on epidemic development of crown rust following focal and general inoculations of mixtures of immune and susceptible oat plants. Phytopathology 75: 11411145 .

50. MUNK, L. 1983. Response of a powdery mildew population to a barley variety mixture. In: Durable Resistance in Crops, ed. F Lamberti, J M Waller, N A Van der Graaf, pp. 105-7. New York: Plenum.

51. NEWTON AC, GUY DC, NADZIAK J, GACEK E, 2002. The effect of inoculum pressure, germplasm selection and environment on spring barley cultivar mixtures efficacy. Euphytica 125: 325-335.

52. NGUGI, H. K. 1998. Epidemiology and management of sorghum anthracnose and leaf blight in Kenya. Ph.D. thesis. University of Reading, UK.

53. NGUGI, H. K., KING, S. B., and JULIAN, A. M. 2001. Simultaneous temporal progress of sorghum anthracnose and leaf blight in crop mixtures with disparate patterns. Phytopathology 91: 720-729.

54. NGUGI, H. K., KING, S. B., ABAYO, G. O. AND REDDY, Y. V. R. 2002. Prevalence, incidence, and severity of sorghum diseases in western Kenya. Plant Disease 86 (1): 65 70 .

55. ODVODY, G. N., and HEPPERLY, P. R. 1992. Foliar diseases of sorghum. Pages: 167-177 in: Sorghum and Millet Diseases: A Second World Review. J. A. de Milliano, R. A. Frederiksen, and G. D. Bengstron, eds. International Crops Research Institute for the Semi-Arid Tropics, Patancheru, India.

56. OSTERGAARD, H. 1983. Predicting development of epidemics on cultivar mixtures. Phytopathology 73: 166-172.

57. PALTI, J. 1981. Cultural Practices and Infectious Crop Diseases. New York: Springer Verlag.

58. PARLEVLIET, J. E. 1981. Stabilizing selection in crop pathosystems: an empty concept or a reality. Euphytica 30: 259-269.

59. PENNYPACKER, S. P., KNOBLE, H. D., ANTle, C. E., MADDEN, L. V. 1980. A flexible model for studying plant disease progression. Phytopathology 70: 232-235.
60. RAM, B., REDHU, A. S., SINGH, S. 1989. Development of rusts and powdery mildew in mixtures of wheat varieties. Cereal Resource Communication 17: 195-201.

61. SIFUENTES BARRERA, J. A. 1989. Evaluation of sorghum genotype mixtures for controlling sorghum leaf blight. College Station, Texas. 83p. (Phylosophy Doctor in Plant Pathology), Texas A\&M University,

62. SUBBA RAO, K. V., BERGGREN, G. T., SNOW, J. P. 1990. Characterization of wheat leaf rust epidemics in Louisiana. Phytopathology 80: 402-410.

63. THAL, W. M., CAMPBELL, C. L., MADDEN, L. V. 1984. Sensitivity of Weibull model parameter estimates to variation in simulated disease progression data. Phytopathology 74: 1425-1430.

64. THRESH, J. M. 1981. Pests, Pathogens and Vegetation: The Role of Weeds and Wild Plants in the Ecology of Crop Pests and Diseases. Massachusetts: Pitman Pub., Inc. 1982. Cropping practices and virus spread. Annu. Rev. Phytopathol. 20: 193218.

65. TODOROVA, M., and KURJIN, H. 1991. Studies on competitive ability of some physiological races of Puccinia recondita Ro. ex Desm. f.sp. tritici Erikss. Cereal Rusts Powdery Mildews Bull 19: 59-64.

66. VALÉRIO, H. M., M. A., RESENDE, WEICKERTOLIVEIRA, R. C. B., CASELA, C. R. 2005. Virulence and molecular diversity in Colletotrichum sublineolum from Brazil. Mycopathologia 159: 449-459.

67. VAlÉRIO, H. M., CASElA, C. R., M. A., RESENDE, SANTOS, F. G. 2004. Variability of the anthracnose fungus Colletotrichum sublineolum in sorghum genotype mixtures. Fitopatologia Brasileira 29(5): 567-569.

68. VANDERPLANK, J. E. 1963. Plant Diseases: Epidemics and Control. New York: Academic Press.

69. VANDERPLANK, J. E. 1982. Host-pathogen Interactions in Plant Disease. New York: Academic Press.

70. VILLAREAL, L. M. M. A., and LANNOU, C. 2000. Selection for increased spore efficacy by host genetic background in a wheat powdery mildew population. Phytopathology 90: 1300-1306.

71. WOLFE, M. S. 2000. Crop strenght through diversity. Nature 406: 681-682.

72. WOLFE, M. S. 1985. The current status and prospects of multiline cultivars and variety mixtures for disease resistance. Annual Review Phytopathology 23: 251-273.

73. WOLFE, M. S., BARRET, J. A. 1980. Can we lead the pathogen astray? Plant Disease 64: 148-155.

74. WOLFE, M. S. 1997. Variety mixtures: concept and value. In: Variety Mixtures in theory and practice, Wolfe, M. S (ed.). European Union Variety and Species Mixtures working group of COST Action 817.

75. WOLFE, M. S.; FINCKH, M. R. 1997. Diversity of host resistance within the crop: effects on host, pathogen and disease, in: H.Hartleb, R.Heitefuss, H.H.Hoppe, (Eds.), Plant resistance to fungal diseases, G. Fischer Verlag, Jena, p: 378400. Annual Review of Phytopathology 16: 159-180.

76. ZADOKS, J. C., SCHEIN, R. D. 1979. Epidemiology and Plant Disease Management. New York: Oxford Univ. Press.

77. ZHU, Y.; CHEN, H.; FAN, J.; WANG, Y.; LI, Y. 2000. Genetic diversity and disease control in rice. Nature 406: 718-722. 